\title{
Znaczenie wywiadu środowiskowego dla postępowania w sprawach nieletnich
}

Potrzeba funkcjonowania instytucji pomocniczych dla wydziałów rodzinnych i nieletnich sądów rejonowych (sądów dla nieletnich) jest niepodważalna. Nie bez powodu instytucje te zostały utworzone niemal tak dawno, jak jedne z pierwszych odrębnych organów rozpoznających sprawy nieletnich, mianowicie sądy pokoju'. Instytucji pomocniczych jest wiele. Różna jest też ich rola. Zwykle mówi się o służbie kuratorskiej oraz zespołach diagnostycznych, niegdysiejszych opiekunach sądowych i Poradni Towarzystwa Przyjaciół Dzieci². Jak pokazują badania, dowody sporządzane przez te instytucje - wywiady środowiskowe i opinie diagnostyczne - pełnią szczególną rolę w postępowaniu z nieletnimi ${ }^{3}$. Dostarczają bowiem informacji o nieletnim i o jego środowisku wychowawczym. I choć są to dowody najbardziej znane oraz z całą pewnością jedne z najlepiej uregulowanych w samej ustawie o postępowaniu w sprawach nieletnich ${ }^{4}$, to $w$ aktach spraw pojawiają się z różną częstością. Zarówno opinia

\footnotetext{
1 Sądy te zostały powołane do życia dekretem Naczelnika Państwa w przedmiocie utworzenia sądów dla nieletnich z dnia 7 lutego 1919 r. (Dz. Pr. P.P. Nr 14, poz. 171).

2 Instytucja opiekuna sądowego została utworzona w 1919 r. na mocy dekretu powołującego do życia sądy pokoju. Jednym z zadań, jakie przypisywano opiekunom było gromadzenie wiedzy o nieletnim i jego rodzinie. Z kolei Poradnia Towarzystwa Przyjaciół Dzieci została utworzona w 1924 r. Świadczyła m.in. porady w zakresie problemów wychowawczych.

3 Por. m.in.: K. Grześkowiak, Nieletni przed sądem, Warszawa 1986, s. 81; M. Korcyl-Wolska, Postępowanie w sprawach nieletnich na tle standardów międzynarodowych, Warszawa 2015, s. 145; B. Czarnecka-Dzialuk, Nieletni sprawcy czynów karalnych przed sadem rodzinnym. Zagadnienia procesowe, Warszawa 1993, s. 79; D. Woźniakowska-Fajst, Nieletnie. Niebezpieczne, niegrzeczne, niegroźne?, Warszawa 2010, s. 218; Z. Rosiak, Sprawy karne nieletnich [w:] Polskie sq̨dy rodzinne w świetle badań empirycznych, red. A. Strzembosz, Warszawa 1983, s. 114; T. Bojarski, E. Kruk, E. Skrętowicz, Ustawa o postępowaniu w sprawach nieletnich. Komentarz, Warszawa 2014, s. 134.

4 Ustawa z dnia 26 października 1982 r. o postępowaniu w sprawach nieletnich (tekst jedn.: Dz. U. z 2018 r., poz. 969; dalej: u.p.n., ustawa o postępowaniu w sprawach nieletnich).
} 
diagnostyczna, do czego przekonuje analiza danych statystycznych ${ }^{5}$, jak i przegląd badań ${ }^{6}$, sporządzane są zwykle w sprawach, w których istnieje ku temu wymóg ustawodawcy, określony w art. 25 u.p.n., a zatem m.in. wtedy, gdy sąd zamierza umieścić nieletniego w młodzieżowym ośrodku wychowawczym lub w zakładzie poprawczym. Znacznie częściej sporządza się wywiad środowiskowy, mimo że na gruncie prawa polskiego nie zostały wprowadzone żadne regulacje w tym zakresie. Odmiennie bowiem niż w przypadku opinii diagnostycznej, u.p.n. nie obliguje sędziego do zlecania przeprowadzenia wywiadu w każdej sprawie. Można by zatem uznać, że praktyka w tym zakresie jest dowolna. Przegląd literatury pokazuje jednak, że powinna być ona jednolita, mianowicie wywiad środowiskowy powinien pojawić się w każdej sprawie nieletniego. Stąd wielu autorów zwracało uwagę na brak wywiadu środowiskowego w aktach spraw, podkreślając przy tym, że wywiad stanowi podstawowe, fundamentalne źródło wiedzy o nieletnim, którego nie można zastąpić żadnym innym dowodem. Przykładowo, w badaniu Heleny Kołakowskiej-Przełomiec i Dobrochny Wójcik, dotyczącym selekcji nieletnich przestępców w sądach rejonowych, wywiad środowiskowy pojawił się w 63,4\% spraw umorzonych w 1979 r. ${ }^{8}$, w badaniu Marianny Korcyl-Wolskiej w 78,6\% i 85,2\% (odpowiednio dla badań z lat 1985 i 1997) ${ }^{9}$. Podobny odsetek zanotował Witold Klaus, badając nieletnich, którzy nie ukończyli trzynastego roku życia10 ${ }^{10}$ Komentując braki w aktach spraw autorzy i autorki tychże badań, zwracali uwagę, że jest to sytuacja niepokojąca, bowiem w tych sprawach, w których wywiad się nie pojawił, sąd nie posiadał podstawowych informacji istotnych dla rozstrzygnięcia sprawy. Poza tym sporządzanie wywiadu w każdej sprawie jest standardem międzynarodowym. Wzorcowe Reguły Minimum Narodów Zjednoczonych dotyczące wymiaru sprawiedliwości wobec nieletnich (Reguły pekińskie), wskazują bowiem na potrzebę przeprowadzenia wywiadu środowiskowego przed wydaniem ostatecznej decyzji we wszystkich sprawach nieletnich, z wyjątkiem tych o drobne przekroczenia ${ }^{11}$.

Wywiad pełni też istotną rolę w prawidłowej realizacji dyrektyw ustawowych - dobra dziecka i indywidualizacji. Obowiązujący w Polsce model postępowania

\footnotetext{
5 Przykładowo, w 2016 r. opiniodawcze zespoły sądowych specjalistów sporządziły 19.708 opinii. W tym roku sędziowie zatrudnieni w wydziałach rodzinnych i nieletnich załatwili razem 71.581 spraw nieletnich (sprawozdanie statystyczne Ministerstwa Sprawiedliwości w sprawach rodzinnych i nieletnich, MS-S16/18 sprawozdania statystyczne Ministerstwa Sprawiedliwości z działalności opiniodawczych zespołów sądowych specjalistów, MS-OZSS-25).

6 Przykładowo, w badaniu z lat 70. XX w. przeprowadzonym pod kierunkiem Adama Strzembosza, opinie pojawiły się w 5\% spraw; w badaniu z 2000 r. Dagmary Woźniakowskiej-Fajst - w 6\%. Mimo upływu wielu lat, praktyka w tym zakresie wydaje się niezmienna. $Z$ kolei w badaniach, które przeprowadziłam w 2015 r. - spraw zakończonych orzeczeniem środka izolacyjnego w postaci umieszczenia w młodzieżowym ośrodku wychowawczym lub w zakładzie poprawczym - opinia pojawiła się w 99\%.

7 Por. m.in. literaturę cytowaną w przypisie 3.

8 Badania zostały przeprowadzone na próbie 504 spraw dotyczących 839 nieletnich - por. H. Kołakowska-Przełomiec, D. Wójcik, Selekcja nieletnich przestępców w sqdach rodzinnych, Wrocław 1990, s. 131.

9 M. Korcyl-Wolska, Postępowanie w sprawach nieletnich na tle..., s. 152.

10 W. Klaus, Dziecko przed sqqdem, Warszawa 2009, s. 194.

11 Przyjęte rezolucją Zgromadzenia Ogólnego NZ 40/33 z dnia 29 listopada 1985 r. Por. reguła 16.1.
} 
z nieletnimi zakłada bowiem dogłębne poznanie nieletniego, które jest możliwe dzięki zgromadzeniu odpowiedniej wiedzy i wykorzystaniu jej w procesie orzekania, w tym wiedzy co do osobowości nieletniego, zwłaszcza jego wieku, stanu zdrowia, stopnia rozwoju psychicznego oraz fizycznego, cech charakteru, zachowania, przyczyn i stopnia demoralizacji, charakteru środowiska, a także warunków wychowania nieletniego ${ }^{12}$. Ustawodawca przewiduje dwa sposoby zdobycia tej wiedzy: bezpośredni - wskutek samodzielnego działania sądu, m.in. poprzez czynności wysłuchania nieletniego i jego rodziców lub opiekunów prawnych, oraz pośredni - angażujący inne instytucje, np. poprzez zlecenie im sporządzenia wywiadu środowiskowego. Istotne jest jednak to, że do ustalenia okoliczności, jakie powinien wziąć pod uwagę sąd w procesie orzekania, zgodnie z dyrektywą indywidualizacji (art. 3 § 2 u.p.n.), nie wystarczą czynności podejmowane przez sąd samodzielnie. Każdy z dowodów gromadzonych w postępowaniu z nieletnimi pełni bowiem inną rolę. Wysłuchanie nieletniego ma jedynie pomóc zorientować się co do kwestii dotyczących nieletniego - jego poziomu rozwoju, zachowania, a także braków prawidłowej socjalizacji, wyrobić sobie pogląd o potrzebach resocjalizacyjnych nieletniego z uwzględnieniem możliwości realizacji tych potrzeb w środowisku wychowawczym. Wysłuchanie rodziców z kolei powinno dostarczyć wiedzy o relacjach występujących w rodzinie nieletniego; o tym, jakie trudności sprawia nieletni, i w jaki sposób środowisko wychowawcze radzi sobie z tymi trudnościa$\mathrm{mi}^{13}$. Wywiad środowiskowy z kolei sporządza się nie w celu orientacji, a najogólniej mówiąc - w celu poznania konkretnych faktów dotyczących nieletniego i jego środowiska ${ }^{14}$. Możemy mówić o faktach, gdyż dane do wywiadu są zbierane od różnych osób, miejsc i instytucji. Rozmowa z nieletnim i jego opiekunami czy wizyta w miejscu zamieszkania są tylko jednymi z wielu. Korzystanie z różnych źródeł z pewnością uwiarygadnia ustalenia kuratora. Podobnej weryfikacji nie jest w stanie przeprowadzić sąd. Zakres okoliczności wymienionych w art. $3 \S 2$ u.p.n. - tj. dyrektywę indywidualizacji w dużej mierze wyczerpuje właśnie wywiad środowiskowy (art. 24 u.p.n.), podobnie zresztą, jak zakres danych o nieletnim, wymieniony w art. 32b u.p.n. Wydaje się zatem, że wywiad środowiskowy jest niezbędny do realizacji dyrektyw ustawowych. Ustalenia w nim poczynione okazują się bowiem istotne dla diagnozy demoralizacji nieletniego, warunków wychowawczych i prognozy przyszłych zachowań. Diagnoza ta z kolei jest niezbędna do wydania orzeczenia o konieczności - bądź też nie - ingerencji w proces wychowania. Brak wywiadu, w moim przekonaniu, uniemożliwia przeprowadzenie diagnozy, zwłaszcza środowiskowej.

\footnotetext{
12 O modelu postępowania z nieletnimi w Polsce, m.in. V. Konarska-Wrzosek, Prawny system postępowania z nieletnimi w Polsce, Warszawa 2013; B. Stańdo-Kawecka, Prawo karne nieletnich: od opieki do odpowiedzialności, Warszawa 2007; A. Walczak-Żochowska, Modele postępowania z nieletnimi [w:] B. Kowalska-Ehrlich, S. Walczak, Prawne i pedagogiczne aspekty resocjalizacji nieletnich, „Prace IPSIR UW", t. 12, Warszawa 1992, s. 37-42; J. Włodarczyk-Madejska, Skazani na wychowanie. Stosowanie środków izolacyjnych wobec nieletnich, Warszawa 2019, s. 57-84.

13 Por. m. in. V. Konarska-Wrzosek, Prawny system postępowania..., s. 169.

14 J.Włodarczyk-Madejska, Skazani na wychowanie..., s. 149.
} 
Podobnie jak w przypadku opinii diagnostycznej, także co do wywiadów środowiskowych w sprawach nieletnich, u.p.n. określa wykonawcę takiej czynności. Zasadą jest sporządzanie wywiadów przez kuratora sądowego. Dopuszcza się jednak możliwość jego wykonania przez inne instytucje, jak choćby: przedstawicieli organizacji społecznych, jednostki Policji, specjalistów z opiniodawczych zespołów sądowych specjalistów. Korzystanie z takich wyjątków, jak postulowała Ewa Żabczyńska, należy ograniczyć do minimum, bowiem realizacja wywiadu jest tylko z pozoru łatwą czynnością ${ }^{15}$. Stąd też w literaturze zwraca się uwagę na kompetencje osób sporządzających wywiad środowiskowy. Kompetencje te są również oceniane przez sędziów. Sposób realizacji wywiadu, jak i wykonawcę tego zadania regulują m.in. ustawa o kuratorach sądowych ${ }^{16}$, ustawa o postępowaniu w sprawach nieletnich oraz rozporządzenie w sprawie szczegółowych zasad i trybu przeprowadzania wywiadów środowiskowych o nieletnich ${ }^{17}$. Z uwagi jednak na specyfikę pracy kuratora, wiele kwestii nie da się uregulować, wiele może pojawić się ad hoc, wymagając odpowiedniej reakcji. Dlatego tak ważne jest doświadczenie w pracy, a to zapewne należy przypisać właśnie kuratorom sądowym, zwłaszcza zawodowym. To właśnie kuratorzy zawodowi są odpowiedzialni za sporządzanie większości wywiadów w sprawach nieletnich, co jest widoczne choćby w sprawozdaniach statystycznych Ministerstwa Sprawiedliwości ${ }^{18}$. Praktykę tę potwierdzają także wyniki przeprowadzonych badań ${ }^{19}$.

Powyższe rozważania można by oprzeć jedynie na dostępnej literaturze, przeglądzie dotychczasowych badań czy obowiązującym prawie. Wydaje się jednak, że ważnym elementem dyskusji o znaczeniu wywiadu środowiskowego dla postępowania z nieletnimi powinna być analiza postrzegania pracy kuratorów sądowych przez samych sędziów. Takiej właśnie analizie został poświęcony niniejszy artykuł. Wykorzystałam w nim badania, które przeprowadziłam samodzielnie w latach 2015-2016 w Zakładzie Kryminologii Instytutu Nauk Prawnych Polskiej Akademii Nauk oraz w Instytucie Wymiaru Sprawiedliwości, w tym badanie akt spraw sądowych, ogólnopolskie badanie sondażowe oraz badanie jakościowe. Badanie aktowe przeprowadziłam na próbie 370 akt spraw dotyczących 397 nieletnich, wobec których w 2015 r. sąd orzekł

15 E. Żabczyńska, Potrzeba działań interdyscyplinarnych w sprawach nieletnich i małoletnich [w:] Diagnoza psychologiczna w sprawach rozpoznawanych przez sądy rodzinne. Materiały na sympozjum, Kraków 1985, s. 247-248.

16 Ustawa z dnia 27 lipca 2001 r. o kuratorach sądowych (tekst jedn.: Dz. U. z 2020 r., poz. 167).

17 Rozporządzenie Ministra Sprawiedliwości z dnia 16 sierpnia 2001 r. w sprawie szczegółowych zasad i trybu przeprowadzania wywiadów środowiskowych o nieletnich (Dz. U. Nr 90, poz. 1010; dalej: rozporządzenie w sprawie wywiadów środowiskowych).

18 W 2018 r. na 335.353 wywiady sporządzone we wszystkich fazach postępowania z nieletnimi, 290.877 z nich wykonali kuratorzy zawodowi, tj. 87\% - por. Sprawozdanie statystyczne Ministerstwa Sprawiedliwości z działalności kuratorskiej służby sq̨dowej, MS-S40r.

19 W badaniu aktowym, którego wyniki przedstawiam w niniejszym artykule, ponad $70 \%$ wywiadów środowiskowych sporządzili kuratorzy zawodowi - por. J. Włodarczyk-Madejska, Stosowanie środka wychowawczego w postaci umieszczenia w młodzieżowych ośrodkach wychowawczych oraz środka poprawczego przez sądy rodzinne i nieletnich w świetle danych statystycznych i badań aktowych, Warszawa 2019 , s. 132-133, https://iws.gov.pl/wp-content/uploads/2018/08/W\%C5\%82odarczyk-Madejska-J_Stosowanie-\%C5\%9Brodka-wychowawczego.pdf [dostęp: 29.04.2020]. 
prawomocnie o skierowaniu do młodzieżowego ośrodka wychowawczego lub o zastosowaniu środka poprawczego (w formie bezwzględnej bądź z warunkowym zawieszeniem jego wykonania). Celem badania była analiza stosowania przez sądy dla nieletnich środków izolacyjnych, szczególnie w kontekście zaleceń zawartych w opiniach diagnostycznych, a także w wywiadach środowiskowych. Ogólnopolskim badaniem sondażowym objęłam trzy grupy zawodowe - sędziów dla nieletnich, zawodowych rodzinnych kuratorów sądowych oraz pracowników opiniodawczych zespołów sądowych specjalistów. Analizie poddałam łącznie 961 ankiet. Był to zwrot na poziomie 16\% w grupie sędziów, 28\% w grupie kuratorów sądowych oraz 33\% w grupie specjalistów z OZSS. Celem badania była analiza współpracy poszczególnych organów i instytucji w zakresie sprawowania wymiaru sprawiedliwości dla nieletnich na etapie zbierania informacji o nieletnim i wydawania orzeczenia o zastosowaniu konkretnego środka wychowawczego lub poprawczego. Kontynuacją i pogłębieniem badania sondażowego były półustrukturyzowane wywiady jakościowe przeprowadzone z 10 przedstawicielami każdej grupy biorącej udział w badaniu sondażowym - łącznie z 30 osobami ${ }^{20}$.

Mówiąc o znaczeniu wywiadu środowiskowego dla postępowania z nieletnimi, niezbędne wydaje się zdefiniowanie pewnych wskaźników, które pozwolą zoperacjonalizować ten termin, a w konsekwencji udzielić odpowiedzi na pytanie, czy wywiad środowiskowy w praktyce ma znaczenie dla postępowania w sprawach nieletnich. Przyjęłam, że wskaźnikami tymi będą: częstość wydawania zarządzeń w przedmiocie sporządzenia wywiadu środowiskowego, zakres informacji zlecanych do ustalenia i przydatnych w procesie orzekania, ocena, czy wywiad jest pomocny, ocena trafności sugestii i wniosków w nim zawartych.

Na tej podstawie postawiłam cztery hipotezy. Założyłam, że wywiad środowiskowy ma znaczenie dla postępowania w sprawach nieletnich, jeśli:

1. Sędziowie zlecają jego sporządzenie w większości spraw.

2. Sędziowie wnioskują o ustalenie informacji, których sami nie są w stanie uzyskać.

3. Sędziowie uznają, że wywiad jest pomocny w podejmowaniu rozstrzygnięcia w sprawach nieletnich.

4. Sędziowie uznają sugestie i wnioski zawarte w wywiadach za trafne.

Dodatkowo sprawdziłam, czy czas oczekiwania na sporządzenie wywiadu może mieć znaczenie dla wydawania zarządzeń o jego przeprowadzeniu, a w tym kontekście przeanalizowałam także czynniki utrudniające terminową realizację zlecenia i czas potrzebny na sporządzenie wywiadu.

Częstość sięgania po dowód z wywiadu, jak już wspomniałam, jest istotna choćby dlatego, że ustawodawca nie obliguje sędziów do gromadzenia wywiadu w każdej sprawie nieletniego. Stąd wysokie odsetki uzyskane w badaniach jeszcze bardziej podnoszą rangę wywiadu. W badaniu sondażowym 96\% sędziów zadeklarowało, że zleca sporządzenie wywiadu środowiskowego w każdej sprawie lub w większości spraw. Ten

20 Szczegółowy opis metodologii i badanych prób, m.in.: J. Włodarczyk-Madejska, Skazani na wychowanie..., s. 99-125. 
wysoki odsetek potwierdzają także ustalenia płynące z badania aktowego. Wywiad został przeprowadzony w stosunku do $84 \%$ nieletnich, tj. 334 na 397 badanych - w połowie na zarządzenie sądu, w połowie - jako sprawozdanie z wcześniej orzeczonego nadzoru (zarówno wobec nieletniego, jak i jego rodzeństwa bądź dozoru nad rodzicami lub opiekunem prawnym nieletniego). W trzynastu sprawach - mimo załączonych sprawozdań - sąd zwrócił się do kuratora sądowego o przeprowadzenie wywiadu; w dwóch z kolei została dołączona teczka nadzoru. Okazuje się jednak, że częstość sięgania po dowód z wywiadu w dużej mierze zależy od wcześniejszego kontaktu nieletniego z sądem. O zależności tej mówili sędziowie w wywiadach jakościowych. Zdają się ją potwierdzać także wyniki badania aktowego. Wśród $16 \%$ spraw bez wywiadu środowiskowego, tylko dwie z nich dotyczyły nieletnich, którzy nie mieli uprzednio spraw w sądzie. Może to oznaczać, że sędziowie dążyli do uzyskania diagnozy środowiskowej nieletnich, co do których stosowali środki izolacyjne, a zatem umieszczenie w młodzieżowym ośrodku wychowawczym lub w zakładzie poprawczym. Mając jednak na względzie izolacyjny charakter tych środków, brak wywiadu w dwóch sprawach należy uznać za zaniedbanie ze strony sądu. Sprawy te z całą pewnością nie należą do spraw o drobne przekroczenia, o których mowa we Wzorcowych Regułach Minimum Narodów Zjednoczonych dotyczących wymiaru sprawiedliwości wobec nieletnich.

W dalszej kolejności sprawdziłam zakres informacji, o jaki zwraca się sąd w zarządzeniu o sporządzenie wywiadu, i które z tych informacji uznaje za najbardziej pomocne w procesie orzekania. Praktyka sądów co do treści zarządzeń jest różna. Niektóre sądy piszą, że wywiad ma zostać przeprowadzony w celu ustalenia danych, o których mowa w art. 24 u.p.n. lub $\S 8$ rozporządzenia w sprawie wywiadów środowiskowych. Inne z kolei - zadają konkretne pytania lub wskazują zagadnienia, o których ustalenie się zwracają. Na podstawie analizy obowiązujących przepisów, jak i wywiadów środowiskowych sporządzonych w badanych sprawach, przygotowałam kafeterię zagadnień, które - zgodnie z przepisami - powinny zostać poruszone w wywiadach, oraz te, które faktycznie się w nich znajdują. W badaniu sondażowym sędziowie mieli możliwość wybrania zarówno tych, o których ustalenie zwykle zwracają się w zarządzeniu o sporządzeniu wywiadu, jak i tych, które ich zdaniem są najbardziej pomocne w rozpoznaniu sprawy. Wśród kwestii, o których ustalenie sąd zwraca się do kuratora, najczęściej były wybierane: zachowanie nieletniego (74\% sędziów wskazało tę odpowiedź), warunki wychowawcze (71\%) i przebieg nauki szkolnej (70\%). Są to dokładnie te same kategorie, które sąd uznaje za najbardziej pomocne w procesie orzekania. Wybrało je odpowiednio $95 \%, 83 \%$ i $80 \%$ sędziów. Kluczowe dla tej hipotezy było sprawdzenie, czy dane, o które sąd zwraca się do kuratora, to dane, których sąd nie jest w stanie pozyskać sam, np. w drodze wysłuchania nieletniego czy jego rodziców lub opiekunów prawnych. Przegląd dostępnej literatury przekonuje, że właśnie tak jest. Niemniej jednak warto sprawdzić, jakich informacji w praktyce dostarcza każdy z tych dwóch dowodów. Wysłuchania nieletnich dołączone do akt badanych spraw były zwykle krótkie i zawierały niewiele - głównie podstawowych - danych o poziomie nauki szkolnej nieletniego, o jego rodzicach (np. czy żyją). W wysłuchaniach rodziców lub opiekunów prawnych pojawiały się dodatkowo krótkie informacje o zachowaniu 
nieletniego. Wydaje się zatem, że na podstawie samodzielnie zgromadzonych danych, sąd mógł się zorientować co do nieletniego i jego aktualnej sytuacji wychowawczej. Z całą pewnością jednak nie wyczerpały one zakresu danych najbardziej przydatnych w procesie orzekania. Słuszny wydaje się także kolejny wniosek, że nawet jeśli dane te udałoby się uzyskać właśnie w drodze wysłuchania, to powinny one zostać zweryfikowane, choćby w szkole czy instytucjach pomocy społecznej.

Skłonność do sięgania po dany dowód może również zależeć od postrzegania tego dowodu jako pomocny w trakcie postępowania. W badaniu sondażowym $86 \%$ sędziów uznało wywiad środowiskowy za bardzo pomocny, $12 \%$ z kolei - za pomocny. Te dobre oceny wystawiane kuratorom i sporządzanym przez nich wywiadom pojawiły się także w uzasadnieniach wydanych przez sąd orzeczeń oraz w rozmowach z sędziami. W uzasadnieniach orzeczeń sędziowie zwracali uwagę na treść dowodu, wnioski w nim zawarte i na kompetencje osób sporządzających wywiad. Wywiady były oceniane jako rzetelnie sporządzone, przekonujące, zrozumiałe i pomocne. W badaniu jakościowym z kolei służba kuratorska została uznana za niezbędną do funkcjonowania sądownictwa dla nieletnich. Pojawiały się wręcz stwierdzenia, że prawidłowo sporządzony wywiad wyklucza konieczność sięgania po inne dowody.

Jakość sporządzanych wywiadów, w ocenie sędziów, jest jednak różna. Od jakości tej zależy z kolei ocena trafności zawartych w wywiadzie sugestii i wniosków. W 334 wywiadach znalazło się 168 zaleceń, z czego 119 dotyczyło orzeczenia środka izolacyjnego, pozostałe m.in. kwestii, takich jak skierowanie na badanie do ośrodka diagnostycznego czy zastosowanie innego środka. Zbieżność orzeczeń sądu z sugestią kuratora była na poziomie 55\%. Podobny poziom wskazywali sędziowie w badaniu sondażowym. W badaniu tym co trzeci sędzia i kurator uznali, że sugestia ma znaczenie w procesie orzekania. Pojawia się ona, zdaniem sędziów, w niespełna 70\% wywiadów. Może to wynikać z tego, że - odmiennie jak w przypadku opinii diagnostycznej - nie istnieje wzór sporządzania wywiadu środowiskowego w sprawach nieletnich. Rozporządzenie mówi jedynie o pisemnej formie wywiadu. Stąd w niektórych okręgach wywiady mają formę opisową, w innych - są to wypełnione kwestionariusze. Być może zmiana w tym zakresie wpłynęłaby korzystnie na częstość zostawiania sugestii i jej uwzględniania w procesie orzekania. Znaczenie dla oceny trafności sugestii zawartych w wywiadzie ma także osoba realizująca wywiad. W badaniu jakościowym trafność ta była oceniana na poziomie 40-90\%, przy czym wyższe noty sędziowie wystawiali wywiadom kuratorów zawodowych. Sędziowie deklarowali także, że liczą się ze zdaniem kuratorów.

Jak już wspomniałam, istotne wydało mi się również sprawdzenie czasu oczekiwania na wywiad. W badaniu aktowym czas ten wyniósł średnio 25 dni. Połowa wywiadów została przeprowadzona w terminie do 14 dni. Zdarzyły się wywiady sporządzone w dniu wydania zarządzenia, jak i takie których czas realizacji wyniósł 250 dni. Trzeba jednak wspomnieć, że na 334 wywiady dołączone do akt badanych spraw, tylko w 9 przypadkach czas ich sporządzenia był dłuższy niż 3 miesiące. W badaniu sondażowym ponad $50 \%$ sędziów odpowiedziało, że czas realizacji wywiadu środowiskowego wynosi tydzień lub dwa, co trzeci ankietowany wybrał odpowiedź „, powyżej 2 tygodni”. 
Również nieco ponad połowa sędziów przyznała, że zdarza im się przypominać o przekroczonym terminie realizacji wywiadu, ale tylko w 4\% sytuacje takie zdarzają się często. Wniosków w tym zakresie nie potwierdziło badanie jakościowe. W badaniu tym sędziowie mówili, że zasadą jest sporządzanie wywiadów w 14-dniowym terminie, jak również, że rzadko przypominają kuratorom o upływie terminu. Analiza ta pozwala uznać, że czas oczekiwania na sporządzenie wywiadu raczej nie ma znaczenia dla decyzji sądu o dopuszczeniu tego dowodu. Poza tym, w przypadku pilnej potrzeby sporządzenia wywiadu, jak mówili sędziowie, kuratorzy są gotowi zrealizować taką czynność niemal natychmiast, co pokazało także badanie aktowe, gdzie część wywiadów została przeprowadzona w dniu wydania zarządzenia przez sędziego. Zdarza się jednak, że kurator nie ma możliwości zrealizowania wywiadu w terminie lub w ogóle. W tej sytuacji niezbędna jest prawidłowa współpraca na linii sędzia - kurator i wypracowanie planu działania. Brak wywiadu, zdaniem większości sędziów, może wiązać się z koniecznością odroczenia rozprawy, a to dlatego, że wywiad, w ich opinii, uznawany jest za niezbędny do wydania orzeczenia w sprawie. Zawiera bowiem kompleksową diagnozę rodziny i nie może zostać zastąpiony ani opinią szkolną, ani wywiadem policyjnym.

O czynniki utrudniające realizację wywiadu (w terminie lub w ogóle) zapytałam kuratorów zawodowych w badaniu sondażowym. Wśród najczęściej podawanych znalazły się: zbyt duża liczba spraw (66,2\%), utrudnienia w kontakcie z rodziną $(52,7 \%)$ oraz zbyt krótki termin zakreślony przez sędziego (37,6\%). Inne to także nieobecność domowników, konieczność rewizyty, błędne dane adresowe, problem w kontakcie z dzielnicowym czy pedagogiem szkolnym. Można zatem uznać, że na terminową pracę kuratorów wpływa przede wszystkim stopień ich obciążenia pracą. Istotna jest tu zwłaszcza jedna z czynności kuratorów, mianowicie wywiady jednorazowe, a zatem wywiady sporządzone w postępowaniu rozpoznawczym. Wywiady te, w opinii kuratorów sądowych, stanowią około $60-80 \%$ czasu pracy. Mimo że są uwzględniane w statystykach Ministerstwa Sprawiedliwości (MS-S40), to nie wliczają się do obciążenia pracą. Przykładowo w 2016 r. liczba wywiadów jednorazowych wyniosła 265.294. Liczba ta przypadała na 2024,8 kuratorów zawodowych oraz 12.086 kuratorów społecznych, przy czym w różnym stopniu. Kuratorzy zawodowi sporządzili 247.159 wywiadów, społeczni zaś - 18.135, a to oznacza, że na jednego kuratora zawodowego przypadły 122 wywiady rocznie, na kuratora społecznego - niespełna dwa. Przy optymistycznym założeniu, że realizacja jednego wywiadu zajmuje jeden dzień roboczy (o tym dalej), a w każdym miesiącu przypada dwadzieścia dni roboczych, w których wywiady te mogą być realizowane, okazuje się, że w cyklu rocznym stanowią one sześć miesięcy dodatkowej pracy kuratorów zawodowych. A to z pewnością wpływa na obciążenie pracą. Obciążenie z kolei ma znaczenie dla jakości wywiadów. Dobrze oddają to wypowiedzi samych kuratorów:

„Nikt do końca nie potrafi nam powiedzieć, jak się ma kodeksowy (...) ośmiogodzinny dzień pracy do zapisu »zadaniowy czas pracy« (...). Nie wykonam wszystkiego w osiem godzin, nie ma takiej opcji. Pomijając to, że to są popołudnia, wieczory, to są dni wolne, bo ja wtedy 
mogę nieletniego zastać (...). Ja nie mam jak rozmawiać z rodzicami, którzy pracują w godzinach dopołudniowych. Musi być [wprowadzony] nienormowany czas pracy w tej sytuacji, żeby w ogóle coś wykonać. Natomiast, tego [zadań zawodowych] jest za dużo". (KW7²1)

„Mamy [miesięcznie], jeżeli chodzi o ilość nadzorów osobistych (...), od 15 do 25. Nie ma szans, żeby [cokolwiek zrobić twórczego] (...), mając 15 nadzorów osobistych, [i do tego], mając tak jak w moim przypadku, (... 65-70 spraw kuratorów społecznych. To jest około 90 spraw miesięcznie. [Do tego trzeba] przeprowadzić jeszcze 25-30 wywiadów w ciągu miesiąca. To [w efekcie] jest tylko (...) taka praca dla pracy, sztuka dla sztuki". (KW5)

"(...) ilość [spraw] (...), które są na głowie kuratora, nieraz uniemożliwia zbieranie [informacji] w tak szerokim spektrum". (KW7)

"(...) jedyną trudnością może być to (...), w jakim okresie nasilenia innych zadań - wpłynie taki wywiad. Bo czasami jest ich więcej, [czasami] jest ich mniej i na pewno tak jest ze wszystkim; czasem mamy świadomość, że mogliśmy, być może, trochę bardziej się przyłożyć". (KW7)

W kontekście zagadnienia trudności mających wpływ na terminową realizację wywiadu znaczenie ma również czas niezbędny do jego przeprowadzenia. W realizacji sądowego zlecenia można wyróżnić dwa etapy: zebranie danych i sporządzenie wywiadu. Czas wykonania każdego z nich jest różny, przy czym zdecydowanie łatwiej oszacować czas sporządzenia wywiadu. Z badania sondażowego wynika, że dla ponad połowy kuratorów to kilka godzin pracy. Zebranie danych z kolei zajmuje różnie - kilka godzin (ok. 40\%) lub kilka dni (25\% wybrało odpowiedź „więcej niż 1 dzień, ale mniej niż tydzień"). Czas ten jest trudny do oszacowania i w dużej mierze zależy od okoliczności wpływających na możliwość zebrania danych. Jeśli uda się zebrać dane przy pierwszym podejściu, to z pewnością sam wywiad sporządzany jest szybciej. Mogą jednak pojawić się czynniki utrudniające w tym m.in. niezastanie domowników, brak możliwości wejścia na posesję (agresywny pies lub furtka zamknięta na kłódkę, brak domofonu) czy nieobecność dyrektora szkoły, ale również udzielanie informacji mało wiarygodnych lub niedostatecznych. W najlepszym przypadku, a zatem przy zebraniu danych za pierwszym podejściem, sporządzenie wywiadu zajmuje jeden dzień roboczy. Jednak wywiady, które udaje się zrealizować w ten sposób, stanowią około 30-40\% ogółem. W pozostałych 60-70\% przypadków pojawia się potrzeba rewizyty, ponownego kontaktu. Warto pamiętać, że kurator nie mieszka w terenie, w którym pracuje. Miejscowości wchodzące w zakres jego rewiru są niekiedy oddalone nawet o kilkadziesiąt kilometrów od siedziby sądów. Jest to o tyle uciążliwe, że kuratorzy nie dysponują samochodami służbowymi. Do pracy na rzecz sądu wykorzystują samochody prywatne. Rekompensatą za to jest nie tyle zwrot delegacji czy kosztów amortyzacji, co dodatek do pensji. Korzystanie w pracy terenowej ze środków transportu

21 Wypowiedziom badanych zostały nadane kody wedle następującej reguły: grupa zawodowa, z której pochodzi respondent (kurator - K), rodzaj badania, z którego pochodzi wypowiedź (wywiad jakościowy - W), numer respondenta. Przykładowo KW7 oznacza siódmy z kolei wywiad jakościowy przeprowadzony z kuratorem zawodowym. 
publicznego wpływałoby negatywnie na czas realizacji poszczególnych czynności. Niekiedy wręcz wykluczałoby ich realizację, np. w sytuacji braku połączeń autobusowych czy kolejowych. Trudności w realizacji wywiadu czasem leżą po stronie nieletniego czy jego rodziców, zwłaszcza wtedy, gdy prezentują roszczeniową postawę, są agresywni czy wręcz przeciwnie, skłonni do wybielania zachowania - swojego i swoich dzieci. Problematyczna okazuje się także współpraca z innymi instytucjami, takimi jak policja czy szkoła. Okazuje się bowiem, że nie zawsze instytucje te są skore do udostępniania danych, o jakie zwraca się kurator, a które są niezbędne do realizacji sądowego zlecenia.

Pomimo wielu trudności, jakie mogą pojawić się przy realizacji wywiadu, wizyta w miejscu zamieszkania przez 94,4\% kuratorów, jak wynika z badania sondażowego, jest uznawana za niezbędną do jego realizacji. Wśród innych obligatoryjnych wybierano: rozmowę z rodzicami lub opiekunem prawnym (96,9\%), rozmowę z nieletnim $(81,7 \%)$, analizę akt (75\%), rozmowę z nauczycielem lub pedagogiem (68\%). Z kolei do grupy źródeł fakultatywnych kuratorzy zaliczali najczęściej rozmowy: z innymi domownikami $(74,3 \%)$, z sąsiadami $(64,4 \%)$, z pracownikiem socjalnym $(68,9 \%)$, z dzielnicowym (62,2\%). Rozporządzenie w sprawie wywiadów środowiskowych nie obliguje do podawania w wywiadzie źródeł będących podstawą podjętych ustaleń, stąd trudno kwestię tę analizować na podstawie badania aktowego. Niemniej jednak warto wspomnieć o dwóch sprawach - wywiadzie umówionym oraz asyście policji przy zbieraniu informacji, zwłaszcza w miejscu zamieszkania nieletniego. Wywiady umówione nie zdarzają się. Są one również niezgodne z rozporządzeniem, jak i nie odzwierciedlają rzeczywistej sytuacji, a taką właśnie zainteresowany jest sąd. Z asysty policji kuratorzy z kolei korzystają bardzo sporadycznie, i to w szczególnie uzasadnionych - głównie kwestią bezpieczeństwa - przypadkach.

Podsumowując, raz jeszcze należy zauważyć, że wywiad środowiskowy jest niezbędnym dowodem w postępowaniu w sprawach nieletnich i ma ogromne znaczenie dla tego postępowania. Zawiera kompleksową diagnozę środowiskową i nie może zostać zastąpiony innym dowodem. Jego znaczenie, w ocenie sędziów, jest niepodważalne. Choć ustawa o postępowaniu w sprawach nieletnich nie obliguje sędziego do zlecenia przeprowadzenia wywiadu środowiskowego w każdej sprawie, to zdaniem wielu autorów, powinien on być sporządzony w stosunku do każdego nieletniego. Również i w moim przekonaniu, taka regulacja powinna znaleźć się w u.p.n. Przeprowadzona analiza dostarcza także innych wniosków. Po pierwsze, istnieje potrzeba etatowego wzmocnienia służby kuratorskiej, ale przede wszystkim zawodowej, na której głównie ciąży obowiązek realizacji wywiadów środowiskowych, i której praca jest oceniana przez sędziów najlepiej. Po drugie, praca kuratora powinna spotykać się z większym uznaniem zarówno sędziów, jak i innych instytucji. W niektórych okręgach bowiem praca ta nie jest doceniana, podobnie jak kwalifikacje i doświadczenie kuratorów. Współpraca w tym zakresie wymaga pewnego usprawnienia. Z badań wynika, że sędziowie nie zawsze mają czas dla kuratora sądowego. Czasem więc kontakt ogranicza się jedynie do przepływu dokumentów. Niechętne do współpracy niekiedy okazują się także inne instytucje, jak policja czy szkoła, które mogą dostarczyć informacji 
istotnych dla wywiadu. Wszystkim tym instytucjom powinno zależeć na jak najlepszej współpracy, bowiem wywiad środowiskowy ma ogromne znaczenie dla postępowania i dalszych losów nieletniego, ale znaczenie to zależy od jakości wywiadów, a jakość ta z kolei w znacznym stopniu uzależniona jest od różnych czynników, jak stopień obciążenia pracą, posiadane wykształcenie, doświadczenie, zakres zebranych danych. Nie sposób jednak mówić o znaczeniu wywiadu dla postępowania z nieletnimi, bez choćby fragmentarycznego pokazania pracy kuratora i doświadczanych przez niego trudności, stąd w artykule także i te kwestie zostały poruszone.

\section{Literatura}

Bojarski T., Kruk E., Skrętowicz E., Ustawa o postępowaniu w sprawach nieletnich. Komentarz, Warszawa 2014.

Czarnecka-Dzialuk B., Nieletni sprawcy czynów karalnych przed sądem rodzinnym. Zagadnienia procesowe, Warszawa 1993.

Grześkowiak K., Nieletni przed sq̨em, Warszawa 1986.

Klaus W., Dziecko przed sq̨em, Warszawa 2009.

Kołakowska-Przełomiec H., Wójcik D., Selekcja nieletnich przestępców w sądach rodzinnych, Wrocław 1990.

Konarska-Wrzosek V., Prawny system postępowania z nieletnimi w Polsce, Warszawa 2013.

Korcyl-Wolska M., Postępowanie w sprawach nieletnich na tle standardów międzynarodowych, Warszawa 2015.

Rosiak Z., Sprawy karne nieletnich [w:] Polskie sądy rodzinne w świetle badań empirycznych, red. A. Strzembosz, Warszawa 1983.

Stańdo-Kawecka B., Prawo karne nieletnich: od opieki do odpowiedzialności, Warszawa 2007.

Walczak-Żochowska A., Modele postępowania z nieletnimi [w:] B. Kowalska-Ehrlich, S. Walczak, Prawne i pedagogiczne aspekty resocjalizacji nieletnich „,Prace IPSIR UW", t. 12, Warszawa 1992.

Włodarczyk-Madejska J., Skazani na wychowanie. Stosowanie środków izolacyjnych wobec nieletnich, Warszawa 2019.

Włodarczyk-Madejska J., Stosowanie środka wychowawczego w postaci umieszczenia w młodzieżowych ośrodkach wychowawczych oraz środka poprawczego przez sądy rodzinne i nieletnich w świetle danych statystycznych i badań aktowych, Warszawa 2019, https://iws.gov.pl/wp-content/uploads/2018/08/W\%C5\%82odarczyk-Madejska-J_Stosowanie-\%C5\%9Brodka-wychowawczego.pdf [dostęp: 29.04.2020].

Woźniakowska-Fajst D., Nieletnie. Niebezpieczne, niegrzeczne, niegroźne?, Warszawa 2010.

Żabczyńska E., Potrzeba działań interdyscyplinarnych w sprawach nieletnich i małoletnich [w:] Diagnoza psychologiczna w sprawach rozpoznawanych przez sądy rodzinne. Materiały na sympozjum, Kraków 1985. 


\section{Streszczenie}

\section{Justyna Włodarczyk-Madejska}

\section{Znaczenie wywiadu środowiskowego dla postępowania w sprawach nieletnich}

Obowiązujący w Polsce model postępowania z nieletnimi zakłada dogłębne poznanie nieletniego, które jest możliwe dzięki zgromadzeniu danych o nieletnim i jego środowisku wychowawczym. Choć ustawa o postępowaniu w sprawach nieletnich nie obliguje sędziego do zlecenia przeprowadzenia wywiadu środowiskowego w każdej sprawie, to zdaniem wielu autorów, powinien on być sporządzony w stosunku do każdego nieletniego. Uznaje się go za podstawowe i fundamentalne źródło wiedzy. To dowód, po który sędziowie sięgają najczęściej. Dostarcza informacji, których nie sposób uzyskać podczas wysłuchania nieletniego czy jego rodziców. Dopuszczenie dowodu z wywiadu środowiskowego pozwala zgromadzić wiedzę pozwalającą poznać nieletniego i podjąć $w$ stosunku do niego rozstrzygnięcie zgodne $z$ obowiązującymi dyrektywami - dobra dziecka i indywidualizacji. Artykuł został poświęcony analizie znaczenia wywiadu środowiskowego w sprawach nieletnich na podstawie wyników badań przeprowadzonych w Instytucie Nauk Prawnych PAN oraz w Instytucie Wymiaru Sprawiedliwości.

\section{Summary}

\section{Justyna Włodarczyk-Madejska}

\section{Importance of a community interview for proceedings in juvenile cases}

When we take into account the model of proceeding with juveniles in Poland, which assumes an in-depth knowledge about juveniles and their families, a community interview is a really important evidence. Although the Act on the proceedings in juvenile cases does not oblige judges to commission a community interview in each case, in the opinion of many authors it should be prepared for each juvenile. It is considered to be the fundamental source of knowledge and it is the evidence most often used by judges as it provides information that cannot be obtained, for example, by hearing juveniles and their parents. The interview also contains information that is necessary for the implementation of statutory directives. The article is devoted to the analysis of the importance of the community interview in juvenile cases based on the results of research carried out at the Institute of Law Studies of the Polish Academy of Sciences and the Institute of Justice.

Słowa kluczowe: nieletni, wywiad środowiskowy, postępowanie w sprawach nieletnich, kurator sądowy, sąd dla nieletnich

Keywords: juvenile, community interview, proceeding in juvenile cases, probation officer, juvenile court 